Reference: Berglund, K-E., Lindberg, M., Nahnfeldt, C. (2016). Social innovation now and then in the Church of Sweden. Diaconia - Journal for the Study of Christian Social Practice. 7(2): 125-141. www.vr-elibrary.de/doi/abs/10.13109/diac.2016.7.2.125\#.WlhNd5OdXaI

\title{
Social innovation now and then in the Church of Sweden
}

Knut-Erland Berglund, $\mathrm{PhD}$ student, Luleå University of Technology

Malin Lindberg, Associate Professor, Luleå University of Technology

Cecilia Nahnfeldt, Associate Professor and Head of Research Unit, The Church of Sweden

\section{Introduction}

Social innovation is a concept that is increasingly being used in European and Scandinavian research, policy and practice. It is perceived as a way to develop sustainable solutions to urgent social needs and societal challenges, such as poverty, unemployment, disabilities, demographic imbalances, etc. (European Commission, 2013; Mulgan et al., 2007). Social innovation refers to the development and implementation of new social practices to improve the quality of life, well-being, relations and empowerment of individuals and communities (Cajaiba-Santana, 2013; Dawson and Daniel, 2010; Pol and Ville, 2009). In that it shares similarities with the diaconal work performed as part of Christian social practices and the welfare services provided by Christian communities and parishes. By pinpointing the innovative aspects of social practices, this concept could serve to further develop our knowledge of how to develop new forms of diaconal work related to welfare services as the social context changes. Based on the results from an ongoing study of innovative social practices in the Church of Sweden, this article scrutinizes the character of a selection of historical and contemporary examples of social innovation in the Church.

The article starts with an account of the main aspects of social innovation found in existing research. In the analysis section this information is used to scrutinize examples of innovative social practices in the Church of Sweden. The study design is then presented and discussed, followed by a contextualizing account of the changing societal role of the Church of Sweden during the last centuries. Thereafter, a selection of historical and contemporary examples of social innovation in the Church of Sweden are described, which are then analyzed based on the main aspects of social innovation from existing research. In the final section, we draw 
conclusions concerning the added value of the study to science, society, and the Christian communities and parishes.

\section{Social Innovation Studies}

The field of social innovation studies has expanded rapidly since a renewed interest in innovative social practices was evoked by socioeconomic transformations in the Western world in the mid-2000s (cf. Buckland \& Murillo, 2013; Cajaiba-Santana, 2013; European Commission, 2013; Grimm et al., 2013; Ionescu, 2015; Mulgan et al., 2007; Philips et al., 2015; Pol \& Ville, 2009). Historical accounts of the conceptual development pinpoint the original introduction of social innovation as a concept to Weber and others around the turn of the 19th century, with sporadic use found during the 20th century by Schumpeter and others until the significant rise in interest during the 21th century (Dawson \& Daniel, 2010; Godin 2012, 2015; Moulaert et al., 2005). During most of the 20th century, a more general concept of innovation was used with respect to technological product development by large companies within the private sector (Blake \& Hanson, 2005; Lindberg, 2012).

This focus served to "technologize" and "industrialize" innovation, by its predominant acknowledgment of product development in technological and industrial settings (Alsos et al., 2013; Andersson et al., 2012). Other actors, sites and forms were marginalized in both policy and research on innovation, for example, small companies, nonprofit organizations, public sector organizations, the services sector and social innovations (Lindberg \& Schiffbänker, 2013). As a reaction to such technological and industrial bias, more inclusive approaches to innovation studies were developed during the early 2000s (Lindberg, 2014, 2015), forming new strands and fields such as that of social innovation (cf. Cajaiba-Santana, 2013; Dawson \& Daniel, 2010; European Commission, 2013; Godin, 2012; Moulaert et al., 2005; Mulgan et al., 2007).

The development of the field of social innovation was accompanied by an increasing public interest in innovative solutions directed toward social needs and societal challenges, as outlined in the Introduction above. This emphasized the need for inclusive processes engaging stakeholders in the development of new solutions to fit their own needs and thus empowering them to influence both society and their own lives (European Commission, 2013; Mulgan et al., 2007). Such social inclusion is an essential part of the main definition of social innovation employed in this article: the development and implementation of new social practices that 
improve the quality of life, well-being, relations and empowerment of individuals and communities (Cajaiba-Santana, 2013; Dawson \& Daniel, 2010; Pol \& Ville, 2009). Social inclusion could be regarded as both a process and a result of social innovation, where as a process it refers to the involvement of stakeholders in the development and implementation of new solutions, thus referring to the intended and/or attained social improvements (Rüede \& Lurtz, 2012). According to Moulaert et al. (2005, pp. 1976-1978), social inclusion can be distinguished from social exclusion as follows:

"'Social inclusion' refers to a condition of (partial) exclusion at the outset, a condition that is to be transformed through institutional changes and agency. Understanding the nature of social exclusion processes is an essential step in the process of determining inclusive actions and strategies."

Thus, the transition from social exclusion to social inclusion is enforced by inclusive actions and strategies evoking institutional changes and agency. Cajaiba-Santana (2013, p. 44) perceives this transition as "new ideas manifested in social actions leading to social change and proposing new alternatives and new social practices." Avelino and Wittmayer (2014, p. 4) conceptualize the transition as "transformative social innovation" by referring to "the process through which social innovation contributes to societal transformation." The conceptualization of the innovative aspect of innovation as new alternatives, new social practices, social change and transformation is further defined by Howaldt and Schwartz (2010, p. 21):

"A social innovation is a new combination and/or new configuration of social practices in certain areas of action or social contexts (...) with the goal of better satisfying or answering needs and problems than is possible on the basis of established practices."

This novelty is distinguishable in new combinations or new configurations of established social practices, which according to Mulgan et al. (2007) is completed by novelty in the adaptation of established practices to new contexts. And Moulaert et al. (2005, p. 1978) noted, the novelty does not even have to be "new": 
"A return to old institutional arrangements or agencies can sometimes be quite innovative in the social sense (for example, the reintroduction of free education for all; free art classes for all citizens). Social innovation in the sense of changes in institutions can, therefore, also mean a return to 'old' institutional forms, forms that could even be considered as reformist. This means that 'novelty' could involve (re)turning to mechanisms towards inclusion - if the old serves inclusion better, then opt for the old."

By distinguishing social innovations as those solutions that "serve inclusion better," Moulaert et al. (2005) highlight the normative aspect of social innovation, articulated by Rüede and Lurtz (2010, pp. 24-25) as being "explicitly oriented towards socially esteemed goals." Socially esteemed goals can be distinguished in the general definition of social innovation as focusing improvements on the quality of life, well-being, relations and empowerment of individuals and communities. On a more specific level, however, socially esteemed goals have to be distinguished for specific groups of individuals and specific communities, based on their history of marginalization in specific areas of life. The contextual estimation may thus vary, depending on the guiding norms of those performing the estimation (cf. Dawson \& Daniel, 2010; Moulaert et al., 2005). This is illustrated by Cajaiba-Santana (2013, p. 44), who states that a social innovation "might be perceived as an improvement by a group and as regression by others."

In summary, the main aspects of social innovation distinguished in previous studies could be considered to encompass social inclusion, innovativeness and normativity. In this article these aspects are employed to analyze examples of social innovation in the Church of Sweden, together with the three main dimensions of social innovation outlined by Moulaert et al. (2005): the content dimension of satisfying human needs that are not currently satisfied, the process dimension of changing social relations to increase the level of participation in general and among deprived groups in particular, the empowerment dimension of increasing sociopolitical and economic capabilities required to satisfy human needs and enable participation.

\section{Research Design}

The article reflects the results from an ongoing study of social innovation in the Church of Sweden during the years 2015-2016. The purpose of the study is to increase the understanding 
of the societal role of the Church of Sweden from a contemporary and historical perspective, by identifying, documenting and analyzing examples of social innovation in the Church. The study involves researchers both from the Research Unit of the Church of Sweden and from Luleå University of Technology in Sweden as well as employees in individual parishes and dioceses, who jointly developed new knowledge in accordance with a participatory research approach (cf. Aagaard Nielsen \& Svensson, 2006; Coghlan \& Brydon-Miller, 2014; Nahnfeldt, 2015). The participatory approach served to generate both practically and theoretically relevant knowledge on the role of the Church of Sweden in the development of innovative social practices, knowledge that could hence be applied in the promotion, management and study of innovative social practices in diaconal work related to welfare services.

The identification and documentation of examples were performed by a combination of literature review, document study, survey, interviews and workshops. The goal was to create and simultaneously encompass an in-depth picture of existing social innovations in the Church of Sweden. The literature review encompassed scientific studies on the societal role of the Church of Sweden over the last centuries. The document study looked at existing reports and other published materials describing examples of innovative social practices in the Church of Sweden. The survey consisted of written questions sent out to all Swedish parishes, which were asked to describe some of their innovative activities in a report to the Church secretariat. The interviews encompassed three semistructured interviews with the initiators of innovative social practices in three dioceses where they were asked to describe how and why they developed and implemented their ideas. The participatory workshops included three groups of employees in parishes, dioceses and the secretariat, who had experience of promoting, developing or implementing innovative social practices in the Church of Sweden. At the workshops, the three groups interacted with the project's researchers in identifying, documenting and analyzing the examples of innovative social practices. The workshops were documented by means of field notes and photos of white board drawings.

All methodologies employed served to identify and document examples of social innovation in the Church of Sweden. The interviews and workshops interpreted the documentation in a multifaceted manner in order to provide nuance to the subsequent analysis. The combination of methods enabled the identification of a variety of examples of innovative social practices in the Church of Sweden; it also documented them in a multifaceted manner and analyzed them 
by means of the participants' various knowledge and experience. The results reflect the variety and complexity of social innovation as outlined in the previous section of this article. The breadth encountered also resulted in methodological challenges, such as the difficulty of delineating examples that had seldom been conceptualized as social innovations before. This required a dual strategy of indirect questions in the survey and interviews about "new" or "innovative" initiatives for social improvements and direct questions explaining the main features of social innovation as outlined in existing research in order to identify similar features in initiatives within the Church of Sweden. The requirement for being considered as an example of social innovation was coherence with the two main aspects of social innovation identified in existing research: innovation and social inclusion (further elaborated in the preceding section).

A selection of the identified examples forms the empirical basis of this article. The selection criteria were: (1) variety in means and aims in order to reflect the multifaceted nature of social innovation in the Church of Sweden; (2) a realization about where the initial ideas had been turned into practice in order to pinpoint examples with prospects of actual social change; (3) structural support where the innovative processes of the parishes were being supported by the dioceses in order to pinpoint examples meeting organizational requirements for realization and dissemination.

\section{The Changing Societal Role of the Church of Sweden}

This section describes the changing societal role of the Church of Sweden from the 19th to the $21^{\text {st }}$ century with respect to the preconditions for developing social innovations in the Church. Throughout this period the Church of Sweden provided various welfare services to various extents, both as part of and in addition to the diaconal work. It is important to note that there is no single view of what the societal role of the Church ought to be. Different theological views provide different views. The development of social practices in the Church of Sweden differs geographically because of differences in the interpretation of piety (Bäckström et al., 2010; Claesson, 2015).

The 19th century was a time of change for the Swedish society in general and for the Church of Sweden in particular. The close relations between the Church of Sweden and the Swedish state had begun to be questioned, something that continued during the following centuries and in 2000 resulted in formally changed relations between church and state (Bäckström et al., 2004; Claesson, 2006; Ekstrand, 2002). Social, economic, demographic and religious changes caused the Church to develop new ways of meeting social needs and challenges. The 
industrialization, urbanization, new communication systems, globalization, migration and secularization that took place during the 19th and 20th centuries also precipitated new religious beliefs, political ideologies and private lifestyles the Church had to integrate into its teaching and tradition. During the second half of the 19th century, several new social practices were developed in the Church of Sweden, such as diaconal work and youth engagement (Bäckström et al., 2010; Claesson, 2006; Hedenborg \& Morell, 2006; Lundin, 2014).

The industrial breakthrough came late but swift in Sweden, and in the early 1900s industry had expanded to become Sweden's largest economic sector. This changed the general living conditions, with increased urbanization and decreasing famines (Nordlund, 2006). New social needs and challenges were being evoked by industrialization and urbanization, for which the Church of Sweden developed services as an alternative to socialism and the Free Churches (Bexell, 2003; Claesson, 2006; Engel, 2006). During the 19th century, industrialists often assumed the main social responsibility for their workers, providing housing, wood, education, libraries, childcare, agricultural land, etc. (Johnson, 2006). The development of the Swedish welfare state during the 20th century formally reduced this responsibility, but the paternalistic relationships nevertheless remained intact in many communes dominated by larger industries (Nordlund, 2006). Often, although not always, the paternalistic model implied a strong commitment to the Church of Sweden in order to maintain social stability among the workers, even if the growth of nonconformist Free Churches and the Temperance Movement had developed into a third path of social negotiation between paternal proprietors and the welfare state (cf. De Geer, 2007; Nordlund, 2006).

New legislation in the 1860 s divided the responsibilities between the municipalities and the Church, where the municipalities took over the responsibility to care for the sick and the poor, while the Church assumed the responsibility for public schooling, an arrangement that existed until 1904, when a public agency for schooling was established (Bexell, 2003; Hedenborg \& Morell, 2006; Lundin, 2014). During the heyday of the Swedish model in the 1930s, an additional agreement was made between the Church of Sweden and the Swedish government, limiting the societal engagement of the Church to religious services and no longer encompassing public welfare services (Johnson, 2006). At the turn of the millennium, the Church of Sweden became legally separated from the state and was transformed into a 
nongovernmental religious body. Today, the Church of Sweden is the largest provider of welfare services besides the public sector (Bexell, 2003; Bäckström et al., 2004, 2010).

\section{Examples of Social Innovation in the Church of Sweden}

Historical and contemporary examples of social innovation in the Church of Sweden may be identified by means of the combined methodologies presented in previous sections. First, two historical examples are presented (Sunday schools and Samariterhemmet), followed by six contemporary examples. The descriptions are quite condensed in order to attain a multifaceted overview of various types of examples, rather than in-depth accounts of individual examples.

Sunday schools, established as a concept in Sweden during the 19th century, aimed at guaranteeing the Christian education of children despite the weakening of the historically strong ties between the Swedish state and the Church of Sweden. The concept was introduced in Sweden by the religious revival movement, inspired by various international models for children Christian education. Though it initially evoked resistance within the Church of Sweden, it was eventually accepted as a new social practice in the Church of Sweden because of the urgent need for maintaining Christian education when public schooling was being increasingly secularized and fewer parents were bringing their children to the regular church services. The dioceses and the national church bodies provided legal and financial prerequisites as well as guidelines for the establishment and management of Sunday schools by the parishes. Each parish, however, determined their own implementation of the Sunday schools, resulting in the adoption of various models throughout the country (Lundin, 2014).

Samariterhemmet, located in the city of Uppsala in Central Sweden, was established in 1882 with the aim of providing healthcare services to the poor. Ebba Boström, an upper-middleclass nurse educated in England, was a driving force for its initiation and development until 1902. The initiator did not see poverty as something predestined and believed that, with the right knowledge and social encouragement, poverty could be overcome. The establishment was also perceived as a place of women's empowerment within the realms of Church of Sweden by providing rare employment opportunities and by acknowledging women's work in social improvement. Samariterhemmet today is organized as a diaconal trust fund closely related to the Church of Sweden and hosts a center for spiritual care within healthcare. Over the years, it has encompassed various entities and activities such as a hospital, an orphanage, a 
hotel, joint housing for people with dementia, nurse's education, etc. (Bexell, 2003; Koivunen Bylund, 1994).

Actor for Welfare, managed by the Västerås diocese in Central Sweden, serves to support the employees in the parishes and diocese, to reflect on the societal role of the Church of Sweden and to develop new ways of working in times of social and organizational transformation. During the process, the employees identified particularly exposed groups, such as the unemployed, sick, youth, elderly and immigrants, as the most important to support since their needs are not sufficiently met by existing public welfare services. This is perceived by the project managers as being similar to the social practices exercised by Jesus, as depicted in stories of Gospels, and as requiring further development of the diaconal work. Several of the employees have participated in competence development on how to organize social companies for the realization of new working methods. The added value of the Church in society is perceived as the ability to combine people's economic, materialistic, social and existential living conditions into all-encompassing solutions for social inclusion. The process was initially organized as a string of projects but has now been integrated into the regular operations of the Church of Sweden.

Open doors and rooms in the Church of Sweden, managed by the Luleå diocese in Northern Sweden, is a process for the social inclusion of people in long-term unemployment stemming from disorders, disabilities, immigration or other reasons through work and management in social companies organized by the Church of Sweden. The process is motivated by the perceived possibilities and responsibilities of the Church to contribute to a more humane society by enabling increased participation. The church offers a wide range of work tasks that suit the multifaceted needs among the unemployed to re-enter the labor market, show their skills and grow personally. As part of the process, the employees in the parishes have acquired support and skills regarding equal treatment, gender equality and social entrepreneurship. A long list of ideas of potential social companies were formulated by the employees and the participants, including catering services, graveyard services, accompanying services and dactylology cafés. An agreement was signed with both the regional and national offices of the Swedish Public Employment Service (Arbetsförmedlingen), establishing the Church as a partner in employment services. 
St Mary, initiated in the city of Lindesberg in Central Sweden, is a concept for social inclusion of people in long-term unemployment because of disorders, disabilities, immigration or other reasons, by providing internships and vocational training in social companies organized by the Church of Sweden. The concept meets the needs for combined employment, skills development and an accepting work environment. It is implemented in cooperation with other social organizations, such as the Swedish Public Employment Service (Arbetsförmedlingen) and regional support organizations for cooperative entrepreneurship (Coompanion). The concept is based on a Christian view of human beings and enhances rehabilitation, empowerment and personal development, guided by the value words meaningfulness, work pride and work fellowship. An innovative combination of several evidence-based methods and perspectives for managing vocational training, personal development and health constitute the concept. The establishment of the concept was enabled by the acceptance of the social company form as a budget post within the Church of Sweden. St Mary is registered as a trademark and the concept is being disseminated to other parishes in Sweden.

Create, located in the city of Eskilstuna in Central Sweden, is a reflexive communication platform where university students, social workers and local residents can interact on the themes of social inclusion, personal development and spiritual exploration by means of expressive arts. The initiator of the platform developed the concept in the 1990s while working as a city social worker and later expanded the idea within the Church of Sweden. The residential area where the platform is located is characterized by various forms of social exclusion, such as unemployment, poverty, addiction, etc. Through art forms such as painting, music, dancing and poetry, the participants get the chance to express their life experiences and explore their spiritual curiosity in a dialog bridging their varying cultural backgrounds, education levels, literacy levels and economic status. This has enabled the Church to renew its role in the local community, now being perceived by new groups of residents as a site for spiritual and personal development and as providing new social practices for tackling challenging life situations.

Gardening house, located in the city of Skellefteå in Northern Sweden, is a social company within the Church of Sweden in which long-term unemployed stemming from disorders, disabilities, immigration or other reasons are enabled to find their way back into the labor market by working in the peaceful environment of a gardening house. The participants get to 
learn the trade of gardening while simultaneously fulfilling their spiritual needs. At the same time, the Church's urgent need for plants at graveyards and funerals is met, with the vision of eventually fulfilling such needs for the whole parish. The garden house is operated in a socially and ecologically sustainable manner, reinvesting the profits in the regular operations and receiving waste heat from the nearby crematory. There is also an idea of producing ecological urns to offer to all parishes with crematories in the northern parts of Sweden, which in turn could extend the operations of the gardening house year round. The urns would be made out of bark, collected at the vast forest premises of the diocese, thus creating work opportunities also in more sparsely populated areas.

Leisure Activity Bank, initiated in the city of Deje in Central Sweden, is a library for sports articles where people can borrow what they need for shorter or longer periods free of charge. The sport articles are donated by people who do no longer need their old bicycles, skis, riding helmets, tennis rackets, ice skates, etc. The main aim is to enhance ecological and social sustainability by recycling instead of consumption, and by enabling common access to healthpromoting leisure activities just like the establishment of public libraries once enabled common access to culture and knowledge. The encouragement of spontaneous sporting activities among children and youth is of particular interest. The leisure activity bank is organized as a social company and was established in cooperation between the Church of Sweden, the municipality and associations for popular adult education. It was then turned into a model that has been disseminated to other places in Sweden, resulting in the establishment of several additional banks.

\section{Analyzing Social Innovation in the Church of Sweden}

The examples of social innovation in the Church of Sweden selected are analyzed in this section based on the main aspects and dimensions of social innovation outlined in previous research. This encompasses the dimensions of content, process and empowerment as well as the themes of social inclusion, innovativeness and normativity.

The content dimension refers to the satisfaction of human needs that are not currently satisfied (cf. Moulaert et al., 2005). The presented examples are concerned with various social and social needs of increased inclusion, in terms of employment, education, community, meaningfulness, spiritual exploration, personal development, health etc. These have been identified among groups whose needs are not sufficiently addressed by existing public welfare 
services, especially among groups perceived as exposed or marginalized in certain social domains such as the unemployed, poor, sick, disabled, elderly, children, youths and immigrants. Satisfaction of these needs is ensured by various measures such as social companies and other sites offering employment, internship, vocational training, management opportunities, rehabilitation, care, community activities, etc. Also included are methods for expressing life experiences, exploring spiritual curiosity, inspiring personal development, enhancing health and rehabilitation, cultivating skills, enabling empowerment, etc. Further, it offers competence development in equal treatment, gender equality, social entrepreneurship, etc. Several of these measures are explicitly based on Christian perspectives on human beings, meaningfulness, work pride, work fellowship, etc.

The process dimension concerns increasing social relations in order to increase the level of participation generally and particularly among deprived groups (cf. Moulaert et al., 2005). The examples presented relate to various forms of relations and participation as part of the transition from social exclusion to social inclusion. Social relations are modified via improved interaction between groups perceived as exposed or marginalized in society as well as established groups such as employers and employees within the Church of Sweden, the Swedish Public Employment Service (Arbetsförmedlingen), associations for popular adult education, etc. Social relations are also modified by initiating dialogues between people with varying cultural backgrounds, education levels, literacy levels, and economic situations. Social relations are changed through the institutionalization of some of the examples, in terms of the establishment of social companies or diaconal trust funds closely related to the Church of Sweden, integration of the operations into the regular operations of the Church as budget posts as well as formal agreements with the Swedish Public Employment Service. Changes in social relations relate to increased participation in terms of employment, internship, vocational training, skills cultivation, management, rehabilitation, personal development, church services/activities attendance, Christian education, etc. These are provided to exposed/marginalized groups as well as to church employees and local residents.

The empowerment dimension refers to the increased sociopolitical and economic capabilities required to satisfy human needs and enable participation (cf. Moulaert et al., 2005). The examples presented comprise efforts to facilitate employment, education, health, relations, etc., among various groups of people. These can be regarded as essential capabilities for being able to influence one's own life-situation as well as one's social context. The added value of 
the Church's sites and methods over existing public welfare services is conceptualized as an open and flexible approach, where each participant's specific needs stemming from life situation, ability, interests and skills are acknowledged and met with an understanding attitude and tailored activities. Another part of the perceived added value is the promotion of spiritual and personal development as part of the Church's provided practices for tackling challenging life situations. The general hypothesis of the Church's innovative social practices is thus that the combination of acceptance, flexibility and spirituality will enhance empowerment by promoting increased sociopolitical and economic capabilities among more or less exposed/marginalized groups. As stated in one of the examples, the ability to combine people's economic, materialistic, social and existential living conditions into allencompassing solutions for social inclusion can be considered one of the main added values of the Church in society and thus also essential to the potential empowerment effects of the Church's social innovations. Since several of the examples encompass diaconal work, which is traditionally one of the most common areas of engagement for women employees and volunteers in the Church, the new social practices developed there could be especially important to female empowerment, by providing employment opportunities and acknowledgement of their efforts for social inclusion and organizational renewal. The available data do not provide sufficient basis to confirm this empirically, however, and neither is there enough data to distinguish whether the same gendered pattern of empowerment exists among the target groups.

Social inclusion is both a process and a result of social innovation, where as a process it refers to the involvement of stakeholders in the development and implementation of new solutions, and as a result flows from the intended and/or attained social improvements (cf. Rüede \& Lurtz, 2012). The main stakeholders in the examples from the Church of Sweden are groups perceived as exposed or marginalized in society because of unemployment, poverty, disabilities, disorders, immigration, age, etc. The data provide few indications of these groups being involved in the development of the new social practices in the Church, but they do offer several testimonies of solutions developed based on the historical and contemporary experiences of the Church in order to identify and meet needs among exposed/marginalized groups. Preceding dialogue and interaction with these groups might thus be regarded as corresponding to stakeholder involvement in the development phase. The data provide more evidence of stakeholder involvement in the implementation of new solutions, where several of the examples are deliberately designed to grant the participants a central role in the 
organization and performance of the main activities to become full-fledged entrepreneurs, employees and/or social actors. The most prominent evidence of social inclusion in the data thus lies in the intended and/or attained social improvements, where all examples have the explicit aim of social inclusion on the labor market and/or in the society.

The innovative aspect pertains to new combinations or new configurations of established social practices as well as innovative adaptation of established practices to new contexts or innovative reintroduction of old mechanisms of inclusion (cf. Howaldt \& Schwartz, 2010; Moulaert et al., 2005; Mulgan et al., 2007). The available data reveal various forms of novelty, examples of new combinations being the management concept connecting methods for vocational training, personal development and health as well as the social company that simultaneously meets professional, spiritual and organizational needs. Examples of new configurations comprise the conceptualization and institutionalization of some measures into trademarks, models, companies, budget posts, etc., thus enhancing longevity and dissemination to other contexts inside or outside the Church of Sweden. It also includes the incorporation of social entrepreneurship in the development of competence among church employees. Examples of contextual adaptation comprise are the use of expressive arts for increased interaction between university students, social workers and local residents, and the initiation of various forms of Sunday schools in Swedish parishes. The most general aspect of innovation unites several of the examples of renewal of the Church's role in response to the general social transformation. This renewal can be regarded in part as a return to old social practices of the Church, from the time when the Church had more formal responsibilities for public welfare services, that are combined and implemented in novel ways in contemporary contexts. The traditional ability of the Church to connect people's economic, materialistic, social and existential living conditions in all-encompassing solutions for social inclusion is performed in new ways in several of the examples analyzed.

Finally, the normative aspect highlights generally esteemed social aims of improvements in the quality of life, well-being, relations and empowerment of individuals and communities, as well as contextually esteemed aims of specific groups and communities (cf. Cajaiba-Santana, 2013; Dawson \& Daniel, 2010; Moulaert et al., 2005; Rüede \& Lurtz, 2010). Most examples reflect a dual normativity of Christian as well as social perspectives on social inclusion, where the Christian perspectives emphasize existential meaningfulness, social community and social participation while the perspective (of the Swedish government) primarily emphasizes 
rehabilitation and labor-market participation. In some of the examples this dual normativity is conceptualized as the added value of the Church to public welfare services, complementing the governmental focus on labor market inclusion with existential and relational aspects of inclusion considered to be prerequisites for attaining thorough social inclusion. The added value is partly distinguishable in the somewhat modified range of exposed/marginalized groups included in the examples from the Church, compared to those pinpointed by the Swedish government, including the poor, children and elderly in addition to the unemployed, sick, disabled, immigrants and youths.

In light of Cajaiba-Santana's (2013, p. 44) description of social innovation as "new ideas manifested in social actions leading to social change and proposing new alternatives and new social practices," an analysis of the aspects and dimensions of social innovation in the examples taken from the Church of Sweden shows that they reflect the elements and phases in Cajaiba-Santana's description through varying forms of social inclusion, innovation, normativity, content, process and empowerment. The specificity of the Church's social innovation compared to regular public welfare services consists of an innovative combination of Christian perspectives on human life, existential meaningfulness, social community and social participation, on the one hand, and governmental aims and means of labor-market inclusion and rehabilitation, on the other hand. This combination is employed in a variety of measures developed, such as employment, internship, vocational training, skills cultivation, management, entrepreneurship. rehabilitation and personal development. These measures are deliberately designed to involve and empower exposed or marginalized groups - such as the unemployed, poor, sick, disabled, elderly, children, youths and immigrants - by combining approaches of acceptance, flexibility and spirituality. In order to enhance longevity and dissemination, several of the measures were conceptualized or institutionalized by trademarks, models, companies, budget posts, etc. Transformative social innovation, conceptualized by Avelino and Wittmayer (2014, p. 4) as "the process through which social innovation contributes to societal transformation," may be distinguished in those examples that concern the transition from idea to implementation, institutionalization and dissemination. The examples analyzed indicate that this requires new ways of identifying groups and needs to be acknowledged by the Church, innovative combinations of traditional and new perspectives and practices, involvement of a wide range of stakeholders in the implementation, the development of competence among employees, as well as institutional ability to incorporate various organizational forms of the implemented measures. 


\section{Discussion}

As stated in the Introduction, the concept of social innovation could serve to further develop our knowledge on how new forms of diaconal work related to welfare services are developed even as the social context of the Church is changing. The historical account indicates that the preconditions for developing social innovations in the Church of Sweden have indeed changed in step with social transformation. As a major social actor during the last centuries due in part to people's private religious engagement, in part to alliances with the industrial proprietors and the state - the Church of Sweden has wielded great power to implement new solutions to social needs and societal challenges. At the same time, this power may also have hampered innovative social practices by conforming to the delimitations set by the formal and informal hierarchies within the Church as well as by the agreements with the industrial proprietors and the state. Regardless of the institutional preconditions, the diaconal work performed by the Church to meet the needs of people in vulnerable life situations, such as poverty, unemployment, loneliness, grief, etc., constituted a pivotal position for socially innovative solutions. The institutional preconditions, however, may have affected the processes, forms and results of these solutions, a topic for further exploration in future studies.

The analysis of the selected examples in this article, performed by means of the main aspects and dimensions of social innovation, offers insights into the development and implementation of innovative social practices in a church in need of renewed social relevance. Several of the examples of social innovation were explicitly initiated in order to redefine the societal role of the Church and to widen the attendance at church services and activities to new groups of residents. By pinpointing the content, process, empowerment, innovation and normativity of social innovation, this analysis highlights pivotal components in the transition from social exclusion to social inclusion in the Church's specific settings. It exposes the social aims, the range of stakeholders and the inclusiveness of processes during the Church's development, implementation and dissemination of innovative social practices. These insights could be employed to identify, acknowledge, promote and manage social innovation in the diaconal work related to welfare services of the perishes, dioceses and other parts of the Church, the goal being to improve the quality of life, well-being, relations and empowerment of both individuals and communities. They could also be employed to further develop the relations and agreements between the Church and public authorities regarding the design and delivery 
of welfare services. These insights could inspire further research on the character and dynamics of innovative social practices in the Church, focusing on questions of institutional restraints/enhancement of their development, implementation and dissemination, fruitful combinations of contemporary and historical perspectives and practices as well as the gendered aspects of empowerment by social innovation.

\section{References}

Aagaard Nielsen, K. and Svensson, L. (Eds.) (2006). Action research and participatory research. Maastricht: Shaker Publishing.

Alsos G.A, Ljunggren, E. and Hytti, U. (2013). Gender and innovation: state of the art and a research agenda. International Journal of Gender and Entrepreneurship, 5(3): 236-256.

Andersson, S., Berglund, K., Thorslund, J., Gunnarsson, E. and Sundin, E. (Eds.) (2012). Promoting Innovation - Policies, Practices and Procedures. Stockholm: VINNOVA.

Avelino, F. and Wittmayer, J. (Eds.) (2014). Game-changers \& Transformative Social Innovation. Working paper, policy insights, lessons for facilitation tools and workshop report. TRANSIT Deliverable 2.1, TRANSIT: EU SSH.2013.3.2-1 Grant agreement no: 613169.

Bexell, O. (2003). Sveriges kyrkohistoria - Folkväckelsens och kyrkoförnyelsens tid. Stockholm: Verbum.

Blake, M. K. and Hanson, S. (2005). Rethinking innovation: context and gender. Environment and planning A. 37(4): 681-701.

Bäckström, A., Edgardh, N. and Pettersson, P. (2004). Religious change in Northern Europe: the case of Sweden: from state church to free folk church: final report. Stockholm: Verbum.

Bäckström, A., Davie, G., Edgardh, N. and Pettersson, P. (eds.) (2010). Welfare and religion in 21st century Europe. Vol. 1, Configuring the connections. Farnham: Ashgate. 
Buckland, H. and Murillo, D. (Eds.) (2013). Antenna for Social Innovation: Pathways to Systemic Change: Inspiring Stories and a New Set of Variables for Understanding Social Innovation. Sheffield: Greenleaf Publishing Limited.

Cajaiba-Santana, G. (2013). Social innovation: Moving the field forward. A conceptual framework. Technological Forecasting \& Social Change. 82: 42-51.

Claesson, U. (2006). En folklig folkkyrka?: historien om Svenska kyrkan och det civila samhället. Det civila samhället som forskningsfält: nya avhandlingar i ett nytt sekel. (pp. 194206). [Publisher and place??]

Claesson, U. (2015). Kris och kristnande: Olof Ekmans kamp för kristendomens återupprättande vid Stora Kopparberget 1689-1713: pietism, program och praktik. Göteborg: Makadam.

Coghlan, D. and Brydon-Miller, M. (2014). The SAGE Encyclopedia of Action Research. London: Sage.

Dawson, P. and Daniel, L. (2010). Understanding social innovation: a provisional framework. International Journal of Technology Management. 51(1): 9-21.

De Geer, H. (2008). Den svenska historien, modellen och förståelsen för CSR, in Nilsson, T. (Ed.). 125 år med Corporate Social Responsibility. Stockholm: Centrum för Näringslivshistoria.

Ekstrand, T. (2002). Folkkyrkans gränser: en teologisk analys av övergången från statskyrka till fri folkkyrka. Stockholm: Verbum.

Engel, C. (2006). Svenska kyrkans sociala arbete - för vem och varför? En religionssociologisk studie av ett diakonalt dilemma. Uppsala: Uppsala universitet.

European Commission (2013). Social innovation research in the European Union: Approaches, findings and future directions. Policy review. Brussels, Belgium: European Commission. 
Godin, B. (2015). Innovation Contested - The Idea of Innovation Over the Centuries. London: Routledge.

Godin, B. (2012). Social innovation: Utopias of Innovation from c. 1830 to the present. Working Paper No. 11, Project on the Intellectual History of Innovation. Montréal: Institut national de la recherche scientifique (INRS).

Grimm, R., Fox, C., Baines, S., and Albertson, K. (2013). Social innovation, an answer to contemporary societal challenges? Locating the concept in theory and practice. Innovation: The European Journal of Social Sciences. 26(4): 436-455.

Hedenborg, S. and Morell, M. (2006). Sverige - en social och ekonomisk historia. Lund: Studentlitteratur.

Howaldt, J. and Schwartz, M. (2010). Social innovation: concepts, research fields and international trends. Dortmund: Sozialforschungsstelle Dortmund.

Ionescu, C. (2015). About the conceptualization of social innovation. Theoretical \& Applied Economics. 22(3): 53-62.

Johnsson, A. (2006). LM-staden - Folkhem $i$ förort. Stockholm: Centrum för näringslivshistoria.

Koivunen Bylund, T. (1994). Frukt icke allenast tro - Ebba Boström och Samarieterhemmet 1882-1902. Doktorsavhandling. Stockholm: Almqvist \& Wiksell international.

Lindberg, M. (2012). A striking pattern - Co-construction of innovation, men and masculinity in Sweden's innovation policy. In Andersson, S., Berglund, K., Thorslund, J., Gunnarsson, E. and Sundin, E., (Eds.). Promoting Innovation - Policies, Practices and Procedures. Stockholm: VINNOVA, pp. 47-67. 
Lindberg, M. (2014). From exclusion to inclusion in public innovation support? Innovative practices in bottom-up networks. Scandinavian Journal of Public Administration. 18(4): 91107.

Lindberg, M. (2015). Democratising Innovation Policy by Gender Scientific Participatory Research. In Gunnarsson, E., Hansen, H. P., Steen Nielsen, B. and Sriskandarajah, N. (Eds.). Action Research for Democracy - New Ideas and Perspectives from Scandinavia. New York: Routledge. [pages??]

Lindberg, M. and Schiffbänker, H. (2013). Entry on gender and innovation. In Carayannis, E. G. (Ed.). Encyclopedia of Creativity, Invention, Innovation and Entrepreneurship. New York: Springer, pp. 782-789.

Lundin, C-H. (2014). Den kyrkliga söndagsskolans och barngudstjänstens etablering $i$ Västerås stift 1900-1916. Masteruppsats. Uppsala universitet.

Moulaert, F., Martinelli, F., Swyngedouw, E. and Gonzalez, S. (2005). Towards Alternative Model(s) of Local Innovation. Urban Studies. 42(11): 1969-1990.

Mulgan, G., Tucker, S., Ali, R. and Sanders, B. (2007). Social innovation. What it is, why it matters and how it can be accelerated. London, England: The Young Foundation.

Nahnfeldt, C. (2015). Motstånd och poetiska fragment. En aktionsforskningsstudie om kunskaper och migration. Tidskrift för genusvetenskap. 36(1-2): 97-118.

Nordlund, T. (2006). Det samhällsbyggande ledarskapet. Om storföretagares inflytande i några svenska kommuner 1900-1950. Arbetsmarknad \& Arbetsliv. 12(2): 115-125.

Phelps, E. (2013). Mass Flurishing - How Grassroots Innovation Created Jobs Challenge and Change. Oxford: Princeton University Press.

Phillips, W., Lee, H., Ghobadian, A., O’Regan, N., and James, P. (2015). Social Innovation and Social Entrepreneurship: A Systematic Review. Group \& Organization Management. 40(3): 428-461. 
Pol, E. and Ville, S. (2009). Social innovation: Buzz word or enduring term? The Journal of Socio-Economics. 38(6): 878-885.

Rüede, D. and Lurtz, K. (2012). Mapping the various meanings of social innovation Towards a differentiated understanding of an emerging concept. Oestrich-Winkel: EBS University. 